\title{
The Syntactic and Semantic Interference of Persian Language among Recent Turkish Speakers of Iran
}

\author{
Behrooz RAHNAMAYEKOOYAN
}

University of Tarbiat Modares, Iran

\section{Shiva HEMATI}

University of Malaya, Malaysia

(C) The Author(s) 2018

\begin{abstract}
Turkish/Azeri and Persian languages have a significant impact on each other due to the frequent interaction between the speakers of two languages. The present study foregrounded on the field study and analysis of 14 Turkish statements made by the recent Iranian Turkish language speakers to investigate the interaction of Persian syntax and semantic among this group. The statistical population has been selected randomly from three groups of the educated people of different sexes in Tabriz city including teenagers, young and middle-aged. The results show that the use of Persian words in Turkish sentences is noticeable, and sometimes it rises up to $60 \%$ and even goes beyond it. The order of words in Turkish sentences is somehow affected by the arrangement of words in Persian sentences. It can also be noted that the rate of impact on the educated group, especially females is much more than the other studied groups.
\end{abstract}

(C)2018.All rights reserved

\section{ARTICLE HISTORY}

Received: $17 / 03 / 2018$

Accepted: 21/06/2018

Published online: 05/10/2018

\section{KEYWORDS}

Syntactic interaction, lexical interaction, Azeri / Azerbaijani language, Farsi language, Turkish language speakers 


\section{Introduction}

The influence and interaction of human languages have been observable for a long time in the field of linguistic. Azeri Turkish and Persian have the significant effects on each other due to some reasons such as tight interaction between the speakers of the two languages, virtually identical religion and culture; and the symptoms are evident in both languages well. However, the rate of interlingual exchange does not align. With regards to the various conditions, the influence of one language from the other one in a two-way interaction will be further, which sometimes may be converted into one-sided interaction. Nowadays, the majority of Iranian Turkish people have an adequate mastery on the Persian language and have an attempt in creating unique works in Persian language. This issue has such a significant result that even the thought of Turkish speaker is full of Persian expressions and it is so affected nowadays that he sometimes gets assistance of the Persian language in shaping his ideas, inner consciousness, words planning, thinking, and the creation of his imagination.

\section{Statement of the problem}

From the view of language teaching science, Persian language is taught to the Iranian Turkish people in multi-faceted style so that the process of learning Persian language for almost all Turkish people begins from childhood, right along with native language through rhymes, and media; and starts its evolution by formal schooling. Nowadays Turkish language in Azeri districts of Iran is spoken as an unofficial and colloquial language and it is seen so far that even writing the Turkish language has been forgotten and few people from the Azeri-Iranian speakers can be found to dominate the writing and reading Azeri Turkish language. In fact, Turkish people of Iran are infected to a kind of "Aphasia" due to inattention to the standards of Azeri Turkish language and lack of proper media. The ambiguity and incoherence of subject and predicate noun, and adjective-noun are some examples. In spite of the relatively acceptable observance of coordination rule of sounds and the use of Turkish-language folklore, Azeri speakers of Iran suffer from major problems in the correct use of their native language, which becomes increasingly complex day by day. Therefore, in this research, the main concern is to examine the role of the Persian language in the linguistic situation of the Turkish people in recent Iran. The first part of this article is an attempt to find suitable answers to the following questions:

- What is the interaction and the use of Persian words by Azeri speakers in their local language?

- To what extent is the Azeri Turkish words construct sentences under the influence of Persian language?The assumptions which are likely to be confirmed at the end of the study include: 
- It seems that the interaction of Persian words and the use of many of them by Azeri speakers of Iran is dramatically observable, because on the one hand, the Persian language is considered the official language of the Islamic Republic of Iran and on the other hand, it is the main language of education in schools and universities, and naturally the majority of media is available in Persian.

It is expected that the Turkish speakers of Iran are influenced too much from the Persian language's arrangement of words in their native language, and this issue is more obvious among the young and educated group, because the Persian language is naturally used more than Azeri Turkish nowadays in Iran with regards to the cases mentioned before in the hypothesis, and Turkish is only limited to the local and oral speech and its writing is practically overlooked.

\section{Objective}

Relying on statements of recent Iranian Turkish language, this study is intended to identify and describe the interaction of words and grammar of the Persian language in the speech of Azeri Iranian at the present time at the first step and, thus, the useful and practical results and information are made available to researchers in the field of linguistics, language, sociology to gain useful achievements. In the next step, we will try to, if possible, achieve the effective solution to minimize the interaction of Persian language among Turkish speakers to teach multi-faceted and successful Persian language in learning other foreign languages in schools, universities and other private institutions.

\section{Methodology}

This paper is essentially based on an analysis of 14 Azeri Turkish statements among 200 speakers of this language and their equivalents in Persian language without the specified time to act confidently. The maximum time an individual has spent to build sentences is not exceed 90 minutes. In addition, recording the statements is made by an expert in Turkish language who read the statements orally to the selected participants. One of the main reasons that lead us to collect information orally is that almost the majority of the Iranian Turkish speakers are no longer able to read and write their native language themselves. Some Turkish speakers can read and write Turkish language through the Latin and Arabic alphabet. In fact, Iranian Turkish speakers learn Persian, Arabic and English during their studies at school and university, and this phenomenon strengthens the interlingual interference of other languages among them. The total population is randomly selected among three groups of teenagers (12-19 years), youth (20-40 years) and middle-aged (41-60 years) in 2017. In the case of older people and children, extralinguistic factors will play a role in the process of enunciating, and 
may circumvent the main goal of this research. As a result, we have consultation with experts in preferring to build upon three important range of age. All those selected populations in this research are educated people from Tabriz as an old city with seven thousand year history which is located in northwestern of Iran and has been the largest and most populous city of Iran who are Turkish-speaking.

\author{
Analysis \\ 1. \\ A: \\ Azeri $\rightarrow$ Abbas ilə Cavadın üzü səpib.

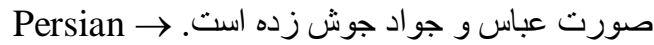 \\ English $\rightarrow$ Abbas and Javad's face has acne.
}

In making the above sentence, the majority of selected adolescents almost conformed to the principle of harmonization of Turkish language sounds, but $45.45 \%$ of the youth and $42.22 \%$ of the middle-aged population were impressed by the Persian language. For example, the two names "Abbas" and "Javad", should be converted into "A'bba's" and "Ja'va'd" in accordance with the rules of the Turkish language. Also, the lack of familiarity of a significant number of people with twofold verbs in their mother tongue has made them unaware of the functionality of these verbs, which can be transient or non-transient. As a result, they have copied the structure of Persian language. In other words, $65 \%$ of the Turkish speakers in this research equated the verb of "having acne" in the same way as Persian, and the Persian word "cuş (acne)" itself does not belong to Turkish language and the remaining 35\% combine "cuş" with other Azeri verbs such as

"tökmək", "səpmək" and other words. In fact, it was expected that in this sentence and the next sentence a double verb of "səpmək" would be used.

B:

Azeri $\rightarrow$ Abbas Cavadın üzünə su səpdi.

Persian $\rightarrow$ عباس به صورت جو اد آب بانشيد.

English $\rightarrow$ Abbas splashed water on Javad's face.

In this sentence, as in the previous sentence, the Turkish speakers in the same way ignored the principle of harmonization of sounds. But the other point to note is that, apart from $27.77 \%$ of the youth, all the tested subjects had correctly used the verb of "səpmək" for the equivalent of the verb of "splash" in Persian.

2.

Azeri $\rightarrow$ Hüseyn bilsə, gedərəm.

Persian $\rightarrow$ اكر حسين بداند، مى روم

English $\rightarrow$ If Hossein knows, I will go. 
Given that the Turkish language is classified as an extension language of suffixes, this language uses a combination of two suffixes, the "sə" and "sa", to express the conditional sentences, and use of each one of these suffixes is based on the rule of the harmony of sounds in Turkish. Therefore, these two suffixes alone are equivalent to "if" in Persian and Persian word "əgər (if)" should not be included in Turkish sentences instead of "sə" / "sa" simultaneously. In this research, unfortunately, only $15 \%$ of the Turkish speakers have followed this rule, which includes the younger generation.

3.

Azeri $\rightarrow$ Bu qolu uzun köynək o qolu qisa köynəkdən daha bahadır.

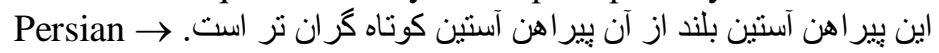
shirt.

English $\rightarrow$ This long sleeved shirt is more expensive than that short sleeve

In addition to the lack of considering the principle of harmony of sounds, in the third sentence, the most important problem encountered in Azeri speakers is the expression of the comparative adjective in Turkish language. They (adolescents: 50\%, youth: $72.72 \%$, and middle-aged: $42.86 \%$ ) have added the term "tor" to the end of the adjective in accordance with the Persian language, while the Turkish language implies to "tər" by adding suffixes of "rək" and "raq" to adjectives; Also, adverbs such as "daha", etc. represent compartive adjective in the Turkish language. $18 / 18 \%$ of the youth and $42 / 42 \%$ of middle aged speakers also used the phrase "long sleeve" in the Turkish language in the same way as Persian language, and sometimes even added the word "əz (from)" of the Persian language for making the comparative adjective instead of using Turkish suffixes "dən" and "dan", which has led to the disruption of the arrangement of words in Turkish language.

4.

Azeri $\rightarrow$ Bu tablo gördüm tabloların ən gözəlidir.

Persian $\rightarrow$ اين تابلو زيباترين تابلوئى است كه ديدام

English $\rightarrow$ This tablau is the most beautiful tablau I saw in the world.

In making this statement, the speakers (adolescents: 100\%, youth: $90 \%$ and middle-aged: $100 \%$ ) have been influenced by the expression of superlative adjectives in Persian language, and instead of "ən", "lap" and ... before the adjective, the Persian suffix of "the most (trrin)" has been inserted to the Turkish language. Moreover, while the Persian language often uses the compound and interpretive sentences to express its purpose, the Turkish language uses one verb and a descriptive word for descriptive terms. All the examined subjects ignored this point and made a compound sentence with the Persian entry word "ke". 5 .

Azeri $\rightarrow$ A. Yazmaq, B. Yazdırmaq, C. Yazdırıtmaq

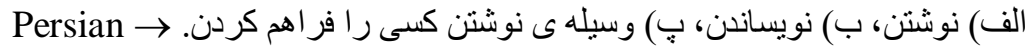

English $\rightarrow$ A. writing, B. Be writen, C. Provide writing means. 
As we know, the transitive verbs can be increased to 3 degrees in Turkish language, which is accomplished by suffixes such as "at, ut, it, dir, dur, etc.". It should be noted that the transitive verb of third degree is specific to the Turkish language and should be relied on sentence in order to convey its meaning in other languages. The recent Turkish speakers were fully successful in finding the correct equivalents of the above verbs in grade 1 . In the case of the transitive verb, grade 2 , the result was also acceptable, as $50 \%$ of adolescents, $72.72 \%$ of youth and $85.71 \%$ of middle aged responded correctly. But unfortunately, none of the examined subjects could make a transitive verb in grade 3 in their mother tongue, in other words, the majority of Iranian Turkish speakers are aliened with the 3rd grade transitive verb and they state that only its audio image has been kept in their minds and they do not know its exact concept and application.

6.

Azeri $\rightarrow$ Heç kəsin ona inanmayacağını biligi üçün heç nə demədi.

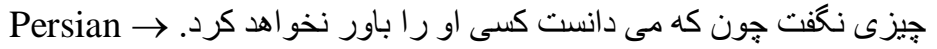

English $\rightarrow$ She did not say anything because she knew nobody would believe her.

In this sentence, like in the 4th sentence, all Turkish speakers have made sentences with the use of the phrase "because" in Persian language entry, and this is contradicted by the syntax of Turkish language, because, as we said earlier, Turkish language often uses descriptive sentences to express its purpose. $50 \%$ of adolescents, $18.18 \%$ of youth and $85.71 \%$ of middle aged also borrowed the Persian word of "belief" and used the verb of "to believe" in their sentences.

7.

Azeri $\rightarrow$ Mən uşaq bağçasıdan çıxan oğlanı gördüm.

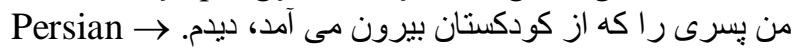

English $\rightarrow$ I saw a boy who came out of kindergarten.

In the 7th sentence, in addition to the fact that we again observe the incorrect use of a compound rather than a descriptive sentence by the Turkish speakers of this research, all the examined subjects used the Persian word of "kindergarten" in the construction of the Turkish term.

8.

Azeri $\rightarrow$ Dünən gecə yağan yağış bütün tarlanı suvardı.

Persian $\rightarrow$ بار انى كه ديشب باريد كل مزر عه را آبيارى كرد د

English $\rightarrow$ The last night's rain irrigated whole farm. 
Although most Turkish speakers have clearly recognized the position of adjective and noun (dünən gecə) and have shown their ability in arranging Turkish words, it still seems that they are incapable of constructing non-compound sentences, since this time, a significant number of them have used the conjunction of "ki (ke)" for expressing their purpose. It should also be noted that $36.36 \%$ of the youth and $57.14 \%$ of the middle aged used the Persian phrase of "whole farm" without any change in their Turkish terms. Finally, 50\% of adolescents and $28.57 \%$ of middle-aged have misinterpreted the Persian verb of "irrigate", so that the first part of the phrase (abyari) is retained and the second part translated into Turkish, which is converted to "abyari eləmək (*making irrigation)".

9.

Azeri $\rightarrow$ Mən sənlə görüşmək istirəm.

Persian $\rightarrow$ من مى خواهم كه بانو ديدار كنم

English $\rightarrow$ I want to meet you.

Fortunately, in the translation of the $9^{\text {th }}$ statement, the teenagers and youth have shown good performance and have not made any significant errors. But the only error that can be mentioned here is the lack of use of descriptive sentences and the reuse of compound words, which was only evident in $42.86 \%$ of middle aged.

10.

Azeri $\rightarrow$ İsti qanlı odunçu ilə dilənçi qucaqlaşdılar.

هيزم فروش خون كرم و كدا همديكر را در آغوش كرفتند. Persian

English $\rightarrow$ the warm-heart Firewood seller and beggar hugged each other.

In this sentence, the most important error of recent Iranian Turkish speakers is the lack of awareness and recognition of the flexibilities and features of the Turkish language verbs. The statistical population, which has been selected from all sorts of people (students, professors, doctors, businessmen, etc.), has clearly shown that participatory verbs of Turkish language are also abandoned among Azerbaijani speakers. Only $9.09 \%$ of the youth and $14.84 \%$ of the middle-aged people use this feature in their native language in the translation of sentences. Another interesting point is that almost the majority of adolescents and youth, and

$28.57 \%$ of middle-aged, did not know the equivalent of Persian words of "seller of firewood" and "warm-heart" in the Turkish language and were forced to use the same Persian words or use the wrong structure of "firewood seller" and so on. Moreover, studies have shown that the arrangement of words in sentences is also influenced by the way in which words are arranged in Persian language; for example, the term "warm-heart" referred in Turkish sentences was brought after the common noun of "firewood seller" by the majority of teens and $45.45 \%$ of the youth, while it was going to be placed before noun in the Turkish language. However, middle-aged have not encountered any particular problem in this case 
and have adhered to the arrangement of Turkish language words. Also, $100 \%$ of adolescents, $54.54 \%$ of youth and $42.84 \%$ of middle aged people tended to use Persian entry of "and" and its Turkish equivalent (ilə).

11.

A:

Azeri $\rightarrow$ Biçaqla bir az belin çərtdi.

Persian $\rightarrow$ با جاقو شكاف جزئى در كمرش به وجود آورد

English $\rightarrow$ He created a minor slit with a knife on his waist.

The lack of awareness of all the studied subjects in this study of double verbs of Turkish again has caused problems in the above sentence and the next sentence, and thus caused the creation of wrong verbs such as: "icad eləmək (creating)" and "icad olmaq (to make)". It is worth recalling that the Turkish verb of "çərtmək" is used as a double act with the meanings of "creating" and "created slit". Few people also translated Persian words "waist" and "slit" into their Turkish words.

B:

Azeri $\rightarrow$ Alını bir az çərtmişdi.

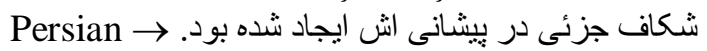

English $\rightarrow$ A little slit was created on his forehead.

In this sentence, recent Iranian Turkish speakers not only did not use the appropriate verb (double verbs), but also used Persian words of "slit" and "forehead" again (adolescents: 25\%, young: 27.27\%, and Middle aged: 57/28\%).

12.

Azeri $\rightarrow$ Mən gün varkan evə qayıtdım

Persian $\rightarrow$ من در حالى كه خورشيد هنوز غروب نكرده بود به خانه بركثتن

English $\rightarrow$ I went back home before sunset.

The "kən" and "kan" in Turkish language are abbreviations of auxiliary verbs of "ikən" and "ikan" respectively with the gerund of "imək", and both transmit the common concepts. In fact, these auxiliary verbs are attached to the end of main verbs in accordance with the principle of harmony of sounds in the Turkish language, and have the meaning of "while," "in a state", and so on. Applying these verbs will not only lead to rhetoric in words, but will also prevent the spontaneity of other languages. Most of the researchers in the study did not have the sufficient mastery in using these auxiliary verbs and inevitably used Persian expressions (for example: "while" and ...). Also, 50\% of adolescents, 9.09\% of youth and $14.28 \%$ of middle aged have used the wrong verb of "ğurub eləmək (Sunset)" in their sentences, since only the elemental part (ğurub) is derived from Persian.

13.

Azeri $\rightarrow$ Yeddi çarpı beş, olur otuz beş. 
هفت ضربدر بنج مى شود سى و بنج. Persian $\rightarrow$ هن

English $\rightarrow$ seven in five equals thirty five.

In this sentence, the $72.77 \%$ of statistical population have translated the phrase "Seven in Five" in the form of "seven multiples five", in which "multiples" is considered as a Persian entry, and other issues except this were not seen related to the interference of the semantic and syntax of Persian language.

14. Azeri $\rightarrow$ Vətəndaşların yüzdə on beşinin doğum günü yaz fəslindədir.

روز تولد يانزده درصد از هم وطنان در فصل بهار است. Persian $\rightarrow$ رو

English $\rightarrow$ The birthday of $15 \%$ of compatriots is in spring season.

Turkish suffix of "daş" is used in terms of companion and partner, which is equivalent to "həm (co-)" in Persian. In this section, all Turkish speakers have used the Persian prefix "həm" for the translation of the word "compatriots" with the neglect of their mother tongue's flexibility. Moreover, unfortunately, among all the studied subjects, only $9.09 \%$ of the young people have been able to express the correct percentage in Turkish language. 50\% of adolescents, $27.27 \%$ of youth, and $57.14 \%$ of middle aged have also used the Persian terms of "from" and "birthday" in the same way in Turkish language, which has led to overlooking the order of Turkish words.

\section{Result and Discussion}

Iranian Turkish speakers have long been interacting with the Persian language speakers due to their close involvement in important topics such as religion, culture, geography, and so on. In such situations, interlingual interaction will be inevitable. In fact, the Turkish language is considered as an interpretive language full of suffixes, in which the words are radically fixed and generally single syllabic and the new semantic and syntactic relations are explained only by adding suffix to it. But the Persian language as an analytic language does not make any changes to it to show the position and meaning of words by using independent words. As it can be seen, Turkish and Persian languages have distinct differences

in terms of their internal structure, however, today there is a tremendous interaction between these two languages. In the present study, based on the descriptiveanalytical method, field studies, collection and analysis of a set of Turkish sentences made by recent Turkish speakers of Iran indicate that the use of the Persian language vocabularies has significantly grown up among Turkish speakers, in a way that

$60 \%$ of the total words used in some Turkish sentences belong to the Persian language, and even in rare cases, this level of interference will go further. 
Moreover, the rule of coordination of sounds, which is a special aspect of Turkish language, is nowadays influenced to a certain extent by the Persian language and, as it should and maybe, it is overlooked. The majority of the studied subjects in this study tended to use the compound sentences in Turkish statements in accordance with the frequently compound and interpreted Persian sentences, while Turkish language was used to express the meaning of semantic sentences. They have also suffered from the lack of knowledge of the twofold verbs in their mother tongue, as a result, they have traced Persian language. A significant number also mistakenly used the Persian phrase "əgər (if)" at the same time with the two Turkish language conditional suffixes of "sə" and "sa". In addition, Turkish speakers have been strongly influenced by the expression of comparative and superlative adjectives in the Persian language.A transitive verb of $3^{\text {rd }}$ grade, which is specific to Turkish language, should at least be presumed abolished among recent Turkish language speakers of Iran, since none of the subjects were able to construct it, and they just stated even after offering the transitive verb grade 3 that they had an audio image of it in their minds and were unaware of their exact meaning. Participatory verbs in the Turkish language are another subject of syntax that the speakers of the study ignored. It should also be noted that they not only did used the Persian conjunctions of "and" and "that" in making Turkish sentences, but also they have not the ability to express issues related to the account (multiplication and percentage). Finally, the modeling of the place of adjective, noun, and ... in the Persian language has more or less disrupted the ordering of words in Turkish sentences. It should be noted that the syntactic and semantic interactions of the Persian language, on the one hand, have a direct relation with the level of education of individuals, so that the higher the level of education, the more interference will be, and on the other hand, this phenomenon is more visible in particular among females.The Persian language teaching methodology for recent Iranian Turkish speakers has proven that the continuity of communication with Turkish/Azerbaijani standard language and its continuous use will also play an effective role in minimizing the interference of Persian semantic and syntax.

In fact, since Farsi is taught multilaterally in Iran, it is expected that this method will be fruitful in learning other foreign languages. For example, in addition to the general issues that arise in teaching a foreign language, it is possible to teach certain curricula (for example, biology) in a foreign language using a foreign language. Therefore, the survey of teaching a language course for Turkish speakers using foreign language in schools can provide interesting research to researchers in this field.

\section{Disclosure statement}

No potential conflict of interest was reported by the authors. 


\section{References and notes:}

Bayani, A. (2013). Read and write like this, Tabriz: Akhtar.

Delija, S., Këçira, R., Ackles, N., \& Iseni, A. (2016). Understanding and Responding to Language Errors. ANGLISTICUM. Journal of the Association for AngloAmerican Studies, 2(3), pp.222-229.

Haghparast Gharamaleki, H. (2007). An analysis of Azeri Turkish through mathematics, Tehran: Andisheh Aria.

Haneda, K. [Translator: Sadigh, H. M.] (2008).Tabrizi vocabulary: an Azeri Turkish dialect in Iran, Tabriz: Yaran.

Heyat, J. (1986). A History of Turkish language and its dialects, Tehran: No

Karang, A. (1962). Contemporary Azerbaijani grammar, Tabriz: Mohammadi.

Khalkhali, A. (2009). Turkish grammar, Tabriz: Yaran.

Mamizadeh, E. \& Shibani Asl, S. (2000). Azeri Turkish on trip, Tehran: Standard.

Mirza Baba Tabib Ashtiani, M. (2007). Turkish grammar, Karaj: Pinar.

Rahmani Khiavi, S. (2013). Azerbaijani grammar, Tabriz: Akhtar.

Zheng, Y., \& Iseni, A. (2017). Authenticity in Language Testing. Anglisticum. Journal of the Association for Anglo-American Studies, 6(8), pp.9-14.

\section{Contact Information}

E-mail: rahnama.behrooz@gmail.com 